\title{
Fiziksel Aktiviteye Katılan Bireylerin İletişim Becerileri ve Sosyal Görünüş Kaygıları
}

\author{
Hüseyin GÖKÇE ${ }^{* 1}$, Kenan KEÇECI' ${ }^{2}$ \\ ${ }^{1}$ Pamukkale Üniversitesi, Spor Bilimleri Fakültesi. https://orcid.org/ 0000-0001-9250-0317. \\ ${ }^{2}$ Pamukkale Üniversitesi, Spor Bilimleri Fakültesi. https://orcid.org/ 0000-0002-8522-5764.
}

Orijinal Makale

Gönderi Tarihi: 28.05.2020

Kabul Tarihi: 27.06 .2020

DOI: 10.30769/usbd.744899

Online Yayın Tarihi: 30.06 .2020

\begin{abstract}
$\ddot{O} \mathbf{z}$
Bu çalışma, bireylerin fiziksel aktiviteye katılan bireylerin iletişim becerileri ile sosyal görünüş kaygılarını incelemek amacıyla yapılmıştır. Çalışma açık, kapalı ve her iki alanda da fiziksel aktiviteye katılan, kolayda örneklem yöntemi ile seçilen 306 kişi ile gerçekleştirilmiştir. Veri toplama aracı olarak araştırmacılar tarafından geliştirilen Genel Bilgi Formu, Etkili Illetişim Becerileri Envanteri, Sosyal Görünüş Kaygısı Ölçeği kullanılmıştır. Verilerin analizinde frekans analizi, tanımlayıcı istatistikler, t-testi, Anova ve Pearson Korelasyon analizleri kullanılmıştır. Cinsiyete göre iletişim becerisi ve sosyal görünüş kaygı puanları karşılaştırılmış, etkin iletişim becerileri ölçeği alt boyutlarından "ego geliştirici dil ve ben dili" alt boyutlarında kadınlar lehine anlamlı fark bulunmuştur $(\mathrm{p}<0,05)$. Medeni durum değişkenine göre iletişim becerileri ve sosyal görünüş kaygı puanları karşılaştırılmış, iletişim becerileri ölçeği "ego geliştirici dil, kendini tanıma açma ve ben dili" alt boyutlarında evlilerin lehine anlamlı farklılıklar bulunmuştur $(\mathrm{p}<0,05)$. Fiziksel aktivite yapılan alana göre iletişim becerileri ve sosyal görünüş kaygı puanları karşılaştırılmış, iletişim becerileri ölçeği "ego geliştirici dil" alt boyutunda açık alanda fiziksel aktiviteye katılanlar lehine anlamlı fark bulunmuştur $(\mathrm{p}<0,05)$. Araştırmanın son probleminde iletişim becerileri ve sosyal görünüş kaygı düzeyleri arasındaki ilişki incelenmiş, iletişim becerileri ölçeği alt boyutları ile sosyal görünüş kaygı ölçeği alt boyutları arasında negatif yönde düşük düzeyde ilişki bulunmuştur ( $r=-, 243 \mathrm{p}<0,01 ; \mathrm{r}=-, 378 \mathrm{p}<0,01 ; \mathrm{r}=-, 365 \mathrm{p}<0,01 ; \mathrm{r}=-, 353 \mathrm{p}<0,05 ; \mathrm{r}=-, 235 \mathrm{p}<0,01)$. Araştırma sonunda, cinsiyet, medeni durum ve fiziksel aktivite yapılan alan iletişim becerisi alt boyutlarında fark oluş̧uran bir faktör iken sosyal görünüş kaygı düzeylerinde herhangi bir anlamlı fark oluşturan faktör değildir. Ayrıca iletişim becerileri alt boyutları ne kadar yüksek olursa, sosyal görünüş kaygının düşeceği sonucu bulunmuştur.
\end{abstract}

Anahtar Kelimeler: Etkili iletişim becerisi, sosyal görünüş kaygı, spor yapılan alan.

\section{Communication Skills and Social Appearance Anxiety of Physical Activity Participants}

\begin{abstract}
This study was conducted to examine the communication skills and social appearance anxieties of individuals participating to the physical activity (outdoor, indoor or both). The study was carried out with 306 people who were open, closed and doing physical activity in both areas, and were chosen by easy sampling method. General Information Form developed by researchers, Effective Communication Skills Inventory, Social Appearance Anxiety Scale were used as data collection tools. Frequency analysis, descriptive statistics, t-test, Anova and Pearson Correlation analysis were used in the analysis of the data. Communication skills and social appearance anxiety scores were compared according to gender, and a significant difference was found in favor of women in the sub-dimensions of "ego developer language and body language", which is one of the effective communication skills scale sub-dimensions ( $\mathrm{p}<0.05$ ). According to marital status variable, communication skills and social appearance anxiety scores were compared, and significant differences were found in favor of married people in the subdimensions of communication skills scale "ego-developing language, self-recognition and body language" ( $p<0.05)$. Communication skills and social appearance anxiety scores were compared according to the field of sports, and a significant difference was found in favor of those participating physical activity in the field of "ego developer language" sub-dimension of communication skills scale ( $\mathrm{p}<0.05)$. In the last problem of the study, the relationship between communication skills and social appearance anxiety levels was examined, and a negative correlation was found between communication skills scale subdimensions and social appearance anxiety scale sub-dimensions $(r=-, 243 p<0.01 ; r=-, 378 p<0.01 ; r=-, 365 p<0.01 ; r=$ $-, 353 \mathrm{p}<0.05 ; \mathrm{r}=-, 235 \mathrm{p}<0.01)$. At the end of the research, while gender, marital status and sports area is a factor that makes a difference in communication skills sub-dimensions, it is not a factor that makes any significant difference in social appearance anxiety levels. Also, the higher the communication skills sub-dimensions, the social appearance anxiety has been found to decrease.
\end{abstract}

Keywords: Effective communication skills, social appearance anxiety, sports area.

*Sorumlu yazar: Hüseyin GÖKÇE, E-posta: hgokce@pau.edu.tr. 


\section{GíRiş}

Teknolojinin ve teknolojiye olan bağımlılığın giderek arttı̆̆ı ve insanların yalnız kaldığı, iletişim kuramadığı, iletişim kurmak istese de bunu yapacak sosyal bir çevrenin olmadığı anda spor devreye girer (Biçer, 1987; Özdinç, 2005). Günümüzde spor, insanları fiziksel, zihinsel ve sosyal olarak geliştirmekle beraber onların duygusal yönden tatmin olmalarını sağlayan bir olgu (Salar, Hekim ve Tokgöz, 2012) olarak karşımıza çıksa da tarihsel gelişimi incelendiğinde çok farklı formatlarda olduğu görülmektedir. İnsanoğlu dönemin ihtiyaçlarına göre sporu farklı amaçlar için kullanagelmiştir. Türk Dil Kurumu (TDK, 2020) tanımına göre spor; "belli kurallara ve tekniklere uyularak yapılan, bedensel gelişmeye yararl, eğlenmek ve yarışmak amacı da bulunan beden hareketlerinin tümünün ortak adı" dır. Sporun tanımında olmayan ancak farklı kaynaklarda belirtilen birçok kazanımı eklemek mümkündür. Bunlardan en başlıcaları arasına iletişim ve sosyalleşmeyi ekleyebiliriz.

Çocukluktan itibaren inceleyecek olursak; birey sporu oyun formatında yaparken, hem fiziksel olarak kendisi için gerekli sağlık ve beceri kazanımlarını tamamlarken; hem de birey olarak yaşadığı toplumun değerlerini, normları ve kuralları anlamasına katkıda bulunmaktadır (Akcan ve Bulgu, 2012). Dolayısıyla çevreyle ve diğer insanlarla ilişki kurma becerileri kazanmada da önemli olduğu düşünülmektedir. Bunların dışında spor ya da fiziksel aktivite, insanlara kişisel kimlik, sosyal kimlik ve grup üyeliği duygusu vererek onları bir araya getirmede kritik bir öneme sahiptir.

Yapısı gereği sosyal bir varlık olarak karşımıza çıkan insan, ilişkilerini iletişim yoluyla sürdürmekte, ilişki kurduğu kişinin duygu, düşünce ve davranışlarını ise sahip olduğu iletişim becerisi düzeyine göre etkileyebilmektedir (Tepeköylü-Öztürk, Soytürk, Daşdan-Ada ve Çamlıyer, 2011). "Sözel olan ve olmayan mesajlara duyarll11k, etkili olarak dinleme ve etkili olarak tepki verme süreci" olan iletişim becerisi (Erözkan, 2010), kişilerarası ilişkilerde psikolojik, sosyal ve ortamsal faktörden etkilenebilmektedir (Sabuncuoğlu ve Gümüş, 2008). İletişim sürecinde bu değişkenlerin ortaya çıkardığı olumsuz durumların azaltılması noktasında spor bir araç görevi üstlenmektedir. Çünkü spor; ırk, cinsiyet, yaş ve kültür ayrımı gözetmeyen yapısı gereği iletişimin kurulmasını destekleyen bir yapıdadır (Yıldıran ve Yetim, 1996). Yapılan çalışmalar da sporun ve sporla ilgili aktivitelerin iletiş̧im becerilerini geliştirdiğini göstermektedir (Tepeköylü-Öztürk, Özbey ve Çamlıyer, 2015). Günümüzde iletişim konusunda en önemli engellerden bir tanesi de fiziksel görünümdür (Dökmen, 1994). Birey iletişime geçerken kendi bedeni hakkındaki olumlu ya da olumsuz düşüncesi bireyin benlik saygısıyla ve dolayısıyla iletişim becerisiyle de ilişkilendirilmektedir (Çelikkol, 2008; Ertürk, 2006; Öngören, 2015). Buradan hareketle bireyin bedenin ya da görüntüsünün başkaları tarafından nasıl algılandığı ile ilgili yargısı (olumlu ya da olumsuz), bireyin o kişilerle nasıl iletişime geçeceğinin önemli bir belirleyici olduğu görüşü çıkmaktadır. Beden imgesinden memnuniyet, sosyal fizik kayg1, sosyal görünüş kaygısı gibi kavramlar tam da bu sebeple ortaya çıkmış kavramlardır. Bedenin dili üzerinde çalışan Baltaş ve Baltaş (1999) iletişim sürecini etkileyen iletişimde ilk dakikanın önemini vurgulamıştır. Bu nedenle göğ̈̈s açıklığı olması gereken düzlemde çevreye açan bireylerin iletişimde daha başarılı olduklarını söylemiştir. Bununla ilgili olarak Tepeköylü-Öztürk ve diğerleri (2015) iletişimde beden duruşunun (postür) önemi üzerinde durmuş spor ve sporla ilgili aktiviteler yoluyla sağlanan 
uygun fiziksel görünümün iletişim becerilerini desteklediğini belirtmiştir. Bireyin özellikle tanımadığı kişilerle yada yeni girdiği ortamlarda başkaları tarafından bedeni ve fiziksel görünüşü ile ilgili olarak olumsuz değerlendirme (Doğan, 2010) olasıllğı hissettiğinde ortaya çıkan kaygıya sosyal görünüş kaygısı denir (Gautreau, Sherry, Mushquash, ve Stewart 2015). Sosyal görünüş kaygısı yüksek olan bireylerin iletişim açısından daha çekingen, içine kapanık tavır sergiledikleri belirtilmiş̧ir (Doğan, 2010). Bunlara ek olarak Iş̧kol Özge (2013) spor yapma durumunun sosyal görünüş kaygıyı azaltan bir etmen olduğunu belirtmiştir. Ayrıca fiziksel görünüm ve sağlık çıktılarının da yine sosyal görünüş kaygı üzerinde fark oluşturan önemli br etmen olduğunu söylemektedir. Dolayısıyla bireylerin çevresiyle etkileşimi sonucu yaşadığı kaygılar kişilerarası iliş̧ileri belirleyici bir faktör olarak ortaya çıkmaktadır (Gordon, Heimberg, Montesi ve Fauber, 2012). Diğer bireylerle etkileşim sağlayan spor yapılan ortamlar düşünüldüğünde farklı mekanlar, farklı alanlar, farklı spor dalları farklı özellikleriyle kişilerarası iletişimi etkileyebilecek bir faktör olarak düşünülmektedir Dolayısıyla, bu alanların seçilmesinde iletişim açısından ya da bireylerin görünümleri ile ilgili değerleri bir etken olabilir mi sorusuyla harekete geçilip mevcut çalışmanın amacı belirlenmiştir. Bu çalışma, fiziksel aktiviteye katılan bireylerin iletişim becerileri ile sosyal görünüş kaygılarının incelenmesi amacıyla tasarlanmıştır.

\section{YÖNTEM}

\section{Araştırma Modeli}

Bu çalışmada betimsel nitelikte ilişkisel tarama yöntemi kullanılmıştır. Karasar'a (2005) göre tarama modellerinin amacı, geçmişte ya da halen var olan bir durumu betimlemektir. İlişkisel tarama modeli ise iki veya daha çok sayıdaki değişken arasında birlikte değişimin varlığını veya derecesini belirlemeyi amaçlar.

\section{Çalışma Grubu}

Araştırmanın evrenini Denizli ili Merkezefendi ve Pamukkale ilçelerinde fiziksel aktiviteye katılan bireyler oluşmaktadır. Araştırmaya dahil edilen bireyler kolayda örnekleme yöntemiyle seçilen 306 kişiden oluşmaktadır. Açı alan, kapalı alan ve her ikisinde de fiziksel aktiviteye katılma durumlarına göre üç gruba ayrılmıştır. Açık alanlarda doğa yürüyüşü, koşu, yürüyüş̧ yapanlar, herhangi bir spor salonunda fiziksel avtiveteye katılanlar ile her iki seçeneği de kullanan bireyler çalışmamıza katılmıştır. Katılımcılara anket formu dağıtıldıktan sonra, anket hakkında detaylı bilgi verilmiş ve doldurmaları için $30 \mathrm{dk}$. süre tanınmıştır.

\section{Veri Toplama Araçları}

Kişisel Bilgi Formu: Katılımcıların cinsiyeti, yaşı, medeni durumu, eğitim durumu, nerede fiziksel aktivite yaptı̆̆ı, haftada kaç gün yaptığı gibi demografik özelliklerini belirlemek için araştırmacı tarafindan oluşturulmuştur.

Etkili Illetişim Becerileri Ölçeği: Buluş ve diğerleri tarafindan 2017'de geliştirilen Etkili İletişim Becerileri Ölçeği 5'li likert tipinde ve 34 maddeden oluşmaktadır. Yönergeyi içeren formda " hiç uygun değil, çok az uygun, kısmen uygun, çoğunlukla uygun, tamamen uygun" şeklinde belirtilmektedir. Ölçek egoyu geliştirici dil, etkin katılımlı dinleme, kendini tanımakendini açma, empati ve ben dili olmak üzere beş alt boyuttan oluşmaktadır. Ölçeğin 
güvenirliği için Cronbach's alpha katsayısı .827 bulunmuştur ve beş madde ise tersten puanlanmıştır. Bu çalışmada iç turarlılık katsayısı .84 bulunmuştur.

Sosyal Görünüş Kaygısı Ölçeği: Hart ve diğerleri tarafından (2008) geliştirilen Sosyal Görünüş Kaygısı Ölçeği'nin Türkçe'ye uyarlaması Doğan (2010) tarafından yapılmıştır. Ölçek 5'li likert tipi 16 maddeden oluşmaktadır. Yönergeyi içeren bu formda "tamamen uygun (5), uygun(4), biraz uygun(3), uygun değil(2), hiç uygun değil(1)" olmak üzere değerlendirilmiş seçenekler yer almaktadır. 1. Madde tersten puanlanmıştır. Ölçekten elde edilen puan ne kadar yüksekse görünüş kaygısının yüksek olduğuna işaret etmektedir. Ölçeğin iç tutarlılık katsayısı .93 olarak bulunmuştur. Bizim çalışmamızda is bu katsayı .78 olarak bulunmuştur.

\section{Verilerin Analizi}

Toplanan veriler istatistik programı ile değerlendirilmiştir. Veriler analiz edilmeden önce normal dağılım açısından incelenmiş olup basıklık çarpıklıkları incelenmiş, yapılan test sonucunda değerler +1 ve -1 arasında olduğu görülmüsstür ve bu değerler arasında verilerin normal dağıldığı kabul edilmiştir (Tabachnick ve Fidell, 2007). Fiziksel aktivite yapan bireylerin cinsiyetlerine, medeni durumlarına, nerede fiziksel aktivite yaptığına göre farka bakmak için Bağımsız Gruplarda T-Testi ve Tek Yönlü Varyans Analizi Testleri ile analiz edilmiştir. Fiziksel aktiviteye katılan bireylerin iletişim becerileri ve sosyal görünüş kayg1 düzeyleri arasındaki ilişkinin incelenmesi amacı ile Pearson Korelasyon analiz tekniği kullanılmıştır.

\section{BULGULAR}

Tablo 1. Katılımcıların Fiziksel aktivite yaptıkları alana göre iletişim becerileri alt boyutları ve sosyal görünüş kaygı düzeylerini gösteren tek yönlü varyans analizi testi sonuçları

\begin{tabular}{|c|c|c|c|c|c|c|}
\hline Değişkenler & & $\mathbf{N}$ & $\overline{\mathbf{x}}$ & SS & f & p \\
\hline \multirow{3}{*}{$\begin{array}{l}\text { Ego } \\
\text { geliştirici dil }\end{array}$} & Kapalı & 130 & 3.87 & .71 & \multirow{3}{*}{6.04} & \multirow{3}{*}{$.003 *$} \\
\hline & Açık & 100 & 4.19 & .64 & & \\
\hline & Her ikisi & 76 & 3.94 & .73 & & \\
\hline \multirow{3}{*}{$\begin{array}{l}\text { Etkin } \\
\text { katılımlı } \\
\text { dinleme }\end{array}$} & Kapalı & 130 & 4.31 & .57 & \multirow{3}{*}{.48} & \multirow{3}{*}{.616} \\
\hline & Açık & 100 & 4.38 & .63 & & \\
\hline & Her ikisi & 76 & 4.30 & .66 & & \\
\hline \multirow{3}{*}{$\begin{array}{l}\text { Kendini } \\
\text { tanıma } \\
\text { açma }\end{array}$} & Kapalı & 130 & 3.51 & .60 & \multirow{3}{*}{.36} & \multirow{3}{*}{.696} \\
\hline & Açık & 100 & 3.57 & .60 & & \\
\hline & Her ikisi & 76 & 3.58 & .64 & & \\
\hline \multirow{3}{*}{ Empati } & Kapalı & 130 & 3.97 & .64 & \multirow{3}{*}{.26} & \multirow{3}{*}{.770} \\
\hline & Açık & 100 & 3.99 & .69 & & \\
\hline & Her ikisi & 76 & 3.91 & .67 & & \\
\hline \multirow{3}{*}{ Ben dili } & Kapalı & 130 & 3.55 & .53 & \multirow{3}{*}{1.66} & \multirow{3}{*}{.190} \\
\hline & Açık & 100 & 3.64 & .52 & & \\
\hline & Her ikisi & 76 & 3.49 & .56 & & \\
\hline \multirow{3}{*}{$\begin{array}{l}\text { Sosyal } \\
\text { görünüsş } \\
\text { kaygı }\end{array}$} & Kapalı & 130 & 1.78 & .75 & \multirow{3}{*}{.08} & \multirow{3}{*}{.923} \\
\hline & Açık & 100 & 1.79 & .63 & & \\
\hline & Her ikisi & 76 & 1.75 & .59 & & \\
\hline
\end{tabular}

Tablo 1 incelendiğinde; iletişim becerileri ölçeği alt boyutlarından yalnızca "ego geliştirici dil" arasında anlamlı bir farklılık görülürken $(\mathrm{p}<0,05)$, diğer alt boyutlar ile sosyal görünüş kayg1 
düzeylerinde anlamlı bir farklılık görülmemiştir. Post-hoc testler incelendiğinde açık alanda fiziksel aktiviteye katılanların ego geliştirici dil alt boyutunda diğerlerinden anlamlı bir şekilde yüksek ortalamaya sahip oldukları görülmektedir.

Tablo 2. Cinsiyet değişkenine göre iletişim becerileri alt boyutları ve sosyal görünüş kaygı düzeylerini gösteren bağımsız gruplarda t testi sonuçları

\begin{tabular}{|c|c|c|c|c|c|c|}
\hline Değişkenler & & $\mathbf{N}$ & $\overline{\mathbf{x}}$ & SS & $\mathbf{t}$ & $\mathbf{p}$ \\
\hline \multirow{2}{*}{ Ego geliştirici dil } & Erkek & 166 & 3.89 & .75 & \multirow{2}{*}{-2.66} & \multirow{2}{*}{$.008 *$} \\
\hline & Kadın & 140 & 4.10 & .63 & & \\
\hline \multirow{2}{*}{$\begin{array}{l}\text { Etkin katılımlı } \\
\text { dinleme }\end{array}$} & Erkek & 166 & 4.28 & .61 & \multirow{2}{*}{-1.67} & \multirow{2}{*}{.096} \\
\hline & Kadın & 140 & 4.39 & .61 & & \\
\hline \multirow{2}{*}{$\begin{array}{l}\text { Kendini tanıma } \\
\text { açma }\end{array}$} & Erkek & 166 & 3.51 & .65 & \multirow{2}{*}{-1.09} & \multirow{2}{*}{.273} \\
\hline & Kadın & 140 & 3.59 & .56 & & \\
\hline \multirow[t]{2}{*}{ Empati } & Erkek & 166 & 3.92 & .68 & \multirow{2}{*}{-1.06} & \multirow{2}{*}{.289} \\
\hline & Kadın & 140 & 4.01 & .65 & & \\
\hline \multirow[t]{2}{*}{ Ben dili } & Erkek & 166 & 3.45 & .53 & \multirow{2}{*}{-4.20} & \multirow{2}{*}{$.000 *$} \\
\hline & Kadın & 140 & 3.70 & .51 & & \\
\hline \multirow{2}{*}{$\begin{array}{l}\text { Sosyal görünüsş } \\
\text { kaygı }\end{array}$} & Erkek & 166 & 1.78 & .70 & \multirow{2}{*}{.02} & \multirow[b]{2}{*}{.984} \\
\hline & Kadin & 140 & 1.77 & .65 & & \\
\hline
\end{tabular}

$* \mathrm{p}<.05$

Tablo 2 incelendiğinde cinsiyet değişkenine göre iletişim becerileri ölçeği alt boyutlarından olan "ego geliştirici dil" [ $\mathrm{t}=-2,66 \mathrm{p}(, 008)<, 05]$ ve "ben dili" alt boyutlarında anlamlı farklılıklar bulunmuştur $[\mathrm{t}=-4,20 \mathrm{p}(, 000)<, 05]$. "Etkin katılımlı dinleme" "kendini tanıma açma" ve "empati" alt boyutlarında anlamlı bir farklılık bulunmamıştır $(\mathrm{p}>, 05)$. Yine cinsiyet değişkenine göre "sosyal görünüş kaygı” düzeyine bakıldığında anlamlı bir farklılık bulunmamıştır (p>,05).

Tablo 3. Medeni durum değişkenine göre iletişim becerileri alt boyutları ve sosyal görünüş kaygı

\begin{tabular}{|c|c|c|c|c|c|c|}
\hline Değişkenler & & $\mathbf{N}$ & $\overline{\mathbf{x}}$ & ss & $\mathbf{t}$ & $\mathbf{p}$ \\
\hline \multirow[t]{2}{*}{ Ego geliştirici dil } & Bekar & 192 & 3.91 & .74 & \multirow{2}{*}{-2.63} & \multirow{2}{*}{$.009 *$} \\
\hline & Evli & 114 & 4.12 & .61 & & \\
\hline \multirow{2}{*}{$\begin{array}{l}\text { Etkin katılımlı } \\
\text { dinleme }\end{array}$} & Bekar & 192 & 4.28 & .64 & \multirow{2}{*}{-1.80} & \multirow{2}{*}{.072} \\
\hline & Evli & 114 & 4.41 & .56 & & \\
\hline \multirow{2}{*}{$\begin{array}{l}\text { Kendini tanıma } \\
\text { açma }\end{array}$} & Bekar & 192 & 3.48 & .63 & \multirow{2}{*}{-2.49} & \multirow{2}{*}{$.013^{*}$} \\
\hline & Evli & 114 & 3.66 & .55 & & \\
\hline \multirow[t]{2}{*}{ Empati } & Bekar & 192 & 3.92 & .67 & \multirow{2}{*}{-1.33} & \multirow{2}{*}{.182} \\
\hline & Evli & 114 & 4.03 & .66 & & \\
\hline \multirow[t]{2}{*}{ Ben dili } & Bekar & 192 & 3.51 & .55 & \multirow{2}{*}{-2.20} & \multirow{2}{*}{$.028 *$} \\
\hline & Evli & 114 & 3.65 & .50 & & \\
\hline \multirow{2}{*}{$\begin{array}{l}\text { Sosyal görünüş } \\
\text { kaygı }\end{array}$} & Bekar & 192 & 1.83 & .74 & \multirow{2}{*}{1.82} & \multirow{2}{*}{.069} \\
\hline & Evli & 114 & 1.69 & .55 & & \\
\hline
\end{tabular}

$* \mathrm{p}<.05$

Tablo 3'e bakıldığında medeni durum değişkenine göre katılımcıların iletişim becerileri ölçeği alt boyutlarından olan "ego geliştirici dil" $[\mathrm{t}=-2,63 \mathrm{p}(, 009)<, 05]$, "kendini tanıma açma" [ $\mathrm{t}=$ $2,49 \mathrm{p}(, 013)<, 05]$, ve "ben dili" $[\mathrm{t}=-2,20 \mathrm{p}(, 028)<, 05]$ alt boyutlarında anlamlı farklılık bulunmuştur. "Etkin katılımlı dinleme" ve "empati" alt boyutlarında anlamlı bir farklılık bulunmamıştır ( $p>, 05)$. "Sosyal görünüş kaygı" düzeyleri ile medeni durum değişkeni arasında da anlamlı bir farklılık bulunmamıştır $(\mathrm{p}>, 05)$. 
Tablo 4. İletişim becerileri alt boyutları ve sosyal görünüş kaygı düzeyi arasındaki ilişkiyi gösteren pearson correlation testi sonuçları

\begin{tabular}{|c|c|c|c|c|c|c|c|}
\hline & & 1 & 2 & 3 & 4 & 5 & 6 \\
\hline \multirow{2}{*}{ 1- Ego geliştirici dil } & $\mathrm{r}$ & \multirow{2}{*}{1} & $.507 * *$ & $.251 * *$ & $.462 * *$ & $.457 * *$ & $-.243 * *$ \\
\hline & $\mathrm{p}$ & & .000 & .000 & .000 & .000 & .000 \\
\hline \multirow{2}{*}{$\begin{array}{l}\text { 2- Etkin katılımlı } \\
\text { dinleme }\end{array}$} & $\mathrm{r}$ & & \multirow{2}{*}{1} & $.418 * *$ & $.564 * *$ & $.347 * *$ & $-.378 * *$ \\
\hline & $\mathrm{p}$ & & & .000 & .000 & .000 & .000 \\
\hline \multirow{2}{*}{$\begin{array}{l}\text { 3- Kendini tanıma } \\
\text { açma }\end{array}$} & $\mathrm{r}$ & & & \multirow{2}{*}{1} & $.469 * *$ & $.289 * *$ & $-.365 * *$ \\
\hline & $\mathrm{p}$ & & & & .000 & .000 & .000 \\
\hline \multirow{2}{*}{ 4- Empati } & $\mathrm{r}$ & & & & \multirow{2}{*}{1} & $.446 * *$ & $-.353 * *$ \\
\hline & $\mathrm{p}$ & & & & & .000 & .000 \\
\hline \multirow{2}{*}{ 5- Ben dili } & $\mathrm{r}$ & & & & & \multirow{2}{*}{1} & $-.235 * *$ \\
\hline & $\mathrm{p}$ & & & & & & .000 \\
\hline \multirow{2}{*}{$\begin{array}{l}\text { 6- Sosyal görünüş } \\
\text { kaygı }\end{array}$} & $\mathrm{r}$ & & & & & & \multirow{2}{*}{1} \\
\hline & $\mathrm{p}$ & & & & & & \\
\hline
\end{tabular}

Tablo 4'te; iletişim becerileri ölçeği tüm alt boyutları ile sosyal görünüş kaygı ölçeği arasında negatif yönde düşük seviyede ilişki olduğu görülmektedir. İlişkileri detaylı olarak gösterecek olursak; ego geliştirici dil -sosyal görünüş kaygı düzeyi $(\mathrm{r}=-, 243 \mathrm{p}<0,01)$; etkin katılımlı dinleme-sosyal görünüş kaygı düzeyi $(\mathrm{r}=-, 378 \mathrm{p}<0,01)$; kendini tanıma açma-sosyal görünüş kaygı düzeyi $(\mathrm{r}=-, 365 \mathrm{p}<0,01)$; empati-sosyal görünüş kaygı düzeyi $(\mathrm{r}=-, 353 \mathrm{p}<0,05)$; ben dilisosyal görünüş kaygı düzeyi $(\mathrm{r}=-, 235 \mathrm{p}<0,01)$ şeklinde sıralayabiliriz.

\section{TARTIŞMA}

Araştırmanın birinci probleminde fiziksel aktivite yapılan alanın iletişim becerisi ve sosyal görünüş kaygıdan etkilenip etkilenmediğinin araştırılmasıdır. Araştırma sonuçlarına göre iletişim becerisi ölçeği alt boyutlarından ego geliştirici dil alt boyutunda açık alanda fizikel aktivite yapanlar lehine anlamlı farklılık oluştuğu görülmüştür. Spor yapısı gereği kendine güveni (Yetim, 2000; Zorba, 2012), benlik saygısını (Saygın, 2008) takım ruhunu destekleyen bir özelliğe sahiptir. Yani açık alanda fiziksel aktivite yapmayı tercih eden bireyler karşıdaki kişiyle iletişim kurarken onun olumlu taraflarını söylemeye gayret gösteren özelliktedir diyebiliriz. Tepeköylü-Öztürk ve diğerleri (2011) yaptıkları çalışmada üniversite öğrencileri ile çalışmışlar, spor yapan öğrencilerin iletişim becerilerinin spor yapmayan öğrencilere göre daha yüksek iletişim becerisine sahip olduklarını belirlemişlerdir. Bir başka çalışmada ise yine Tepeköylü ve diğerleri (2009) spor bilimleri fakültesindeki öğrencilerinin iletişim becerisi algılarının oldukça yüksek olduklarını bulmuşlardır. Sosyal görünüş kaygısı ile spor yapan alan arasında herhangi anlamlı bir fark bulunamamıştır. Gökçe ve diğerleri (2018) yaptıkları çalışmada sosyal görünüş kaygısı yüksek bireylerin spor yaparken daha çok tenha saatleri tercih ettiklerini belirtmişlerdir. Bulunan sonucun farklı olmasının sebebi iki çalışmada örneklemi oluşturan bireylerin spor bilinçlerinin farklı olmasından kaynaklanabilir. İnsanlar farklı sebeplerle farklı ortamlara girmekten imtina edebilirler.

Araştırmanın bir diğer probleminde ise cinsiyete göre iletişim becerileri ve sosyal görünüş kaygıları incelenmiş, ego geliştirici dil ve ben dili alt boyutlarında kadınların ortalamalarının erkeklere oranla daha yüksek olduğu bulunmuştur. Sonuca dayanarak, kadınların erkeklere oranla iletişim kurarken daha çok pozitif geri bildirimler verdiğini ve iletişim kurarken kendi 
duygu ve düşüncelerini aktarmayı daha çok tercih ettikleri söylenebilir. Tepeköylü-Öztürk vd., (2011) üniversite öğrencileriyle yaptıkları çalışmada, kadınların iletişim becerilerinin erkeklere oranla daha yüksek olduğu sonucuna ulaşmışlardır. Bu sonuca paralel sonuçlar alanyazında oldukça fazladır (Bozkurt vd., 2003; Saygıdeğer, 2004). Diğer alt boyutlarda ve sosyal görünüş kayg1 puanlarında herhangi bir anlamlı farka rastlanmamıştır. Alemdağ ve Öncü (2015) öğretmen adaylarıyla yaptıkları çalışmada cinsiyet değişkenine göre sosyal görünüş kaygı puanları arasında fark olduğunu bulmuşlardır. Erkeklerin kadınlara oranla ortalama puanlarının fazla olduğunu bildirmişlerdir.

Bir diğer problemde medeni duruma göre iletişim becerileri ve sosyal görünüş kaygıları karşılaştııılmış, iletişim becerileri ölçeği alt boyutlarından olan ego geliştirici dil, kendini tanıma açma ve ben dili alt boyutlarında anlamlı farklılık bulunmuştur. Ortalama puanlar incelendiğinde evlilerin ortalama puanlarının daha yüksek olduğunu görüyoruz. Etkin katılımlı dinleme ve empati alt boyutlarında yine evli bireylerin ortalamalarının yüksek olduğunu ancak, anlamlı bir farklılık bulunmadığı görülmektedir. Evli bireylerin yaşantıları gereği daha çok paylaşımda bulunmaları bazı yönlerden iletişim becerilerini geliştirdiğini söyleyebiliriz. Kumcağız, Yılmaz, Çelik, ve Avcı, (2011). Hemşirelerle gerçekleştirdikleri çalışmalarında medeni durum değiş̧kenine göre iletişim becerileri arasında herhangi bir fark bulamamışlardır. Hergüner ve Yaman (1997) yaptıkları çalışmada yine medeni durum değişkenine göre anlamlı bir farklılık bulmamışlardır. Yine sosyal görünüş kaygı düzeyleri ile medeni durum değişkenine göre bekarların ortalaması daha yüksek bulunsa da, anlamlı bir farklılık bulunmamıştır ( $\mathrm{p}>, 05)$. Pehlivan, Ada ve Öztaş (2017), ev kadınlarının sosyal görünüş kaygıları ve sağlıklı yaşam biçimi davranışlarını incelemişler ve medeni durumlarına göre sosyal görünüş kaygıları arasında farka rastlamamışlardır. Göksel, Caz, Yazıcı ve Zorba (2018) spor hizmeti alan bireylerle gerçekleştirdikleri çalışmada yine medeni durum değişkenine göre sosyal görünüş kaygı da anlamlı bir farklılık görememişlerdir. Bu noktada çalışmamızda bireylerin farklı meslek gruplarından olması ve fiziksel aktivite değişkenin evli bireylerin iletişimlerini arttıran bir etmen olduğu söylenebilir.

Son olarak sosyal görünüş kaygısı ile iletişim becerisi ölçek puanları arasındaki ilişki incelenmiş, iletişim becerisi ölçeği tüm alt boyutları ile sosyal görünüş kaygı ölçeğinin negatif yönde düşük düzeyde ilişkili olduğu bulunmuştur. Sosyal bir varlık olan insan karşısındakiyle iletişime geçmede ileti̧şim şeklini ve derecesini belirleyen bir takım değerlendirmelerde bulunur, bunlardan en önemlilerinden birisi de fiziksel görünümdür (Kıllı̧, 2015). Çalışmamızın bu sonucu literatürü destekler niteliktedir, sosyal görünüş kaygısı yükseldikçe, iletişim becerisinin azaldığı görülmektedir. Doğan, Sapmaz, ve Totan (2011), bireyin vücuduyla ilgili düşünceleri sonucunda olumlu ve olumsuz bir tutum oluşacağını belirtmektedir, işte bu tutumlar da karşımızdakiyle iletişimimiz bütün boyutlarını etkileyen faktörlerden birisidir. Olumsuz beden algısı, karşı tarafın bireyle ilgili olumsuz değerlendirme yapacağı düşüncesi, sosyal görünüş kaygısını o da muhtemel olarak iletişime geçmeme ya da farklı bir iletişim aracı kullanma (sanal) davranışını getirecektir (Çakmak, 2014). Bu nokta çalışmanın çıkış noktasını oluşturmaktadır. Alan yazın incelendiğinde iletişim becerisi ve sosyal görünüş kaygı ilişkisinin incelendiği başka bir çalışmaya rastlanmamıştır. 
Araştırma sonucunda, cinsiyet, medeni durum, fiziksel aktivitenin nerede yapıldı ğı, iletişim becerisi bazı alt boyutlarında istatistiksel olarak anlamlı fark oluşturan bir faktör iken, sosyal görünüş kaygı düzeylerinde herhangi bir etkisinin olmadığı görülmektedir. Ayrıca iletişim becerisi ile sosyal görünüş kaygının birbirinin tersi yönde hareket ettikleri sonucu bulunmuştur.

\section{KAYNAKLAR}

Akcan, F., \& Bulgu, N. (2012). Spora yönelik sosyalizasyon süreci: Lise öğrencileri üzerine bir uygulama. Spor Bilimleri Dergisi, 23(4), 195-206.

Alemdağ, S., \& Öncü, E. (2015). Öğretmen adaylarının fiziksel aktiviteye katılım ve sosyal görünüş kaygılarının incelenmesi. International Journal of Science Culture and Sport (IntJSCS), 3, 287-300.

Biçer, T. (1987). Spor ve Turizm. Yükseklisans Tezi. İstanbul Üniversitesi, Sosyal Bilimler Enstitüsü, İstanbul.

Bozkurt, N., Serin, O., Emran, B. (2003). İlköğretim birinci kademe ögretmenlerinin problem çözme, iletişim becerileri ve denetim odă̆ l düzeylerinin karşılaştırmalı olarak incelenmesi. 12. Eğitim Bilimleri Kongresi Bildirileri. 1373-1392, Antalya

Buluş, M., Atan, A., \& Erten Sarıkaya, H. (2017). Etkili iletişim becerileri: Bir kavramsal çerçeve önerisi ve ölçek geliştirme çalışması. International Online Journal of Educational Sciences, 10 (10), 2-16.

Çelikkol, A. (2008). Egzersiz ve Benlik Kavramı. http://www.celikkol.org/benlikkavrami.html. Erişim tarihi; 12.01.2020.

Doğan, T. (2010). Sosyal Görünüş Kaygısı Ölçeği’nin (SGKÖ) Türkçe uyarlaması: geçerlik ve güvenirlik çalışması. Hacettepe Üniversitesi Ĕ̈itim Fakültesi Dergisi, 39(39), 151-159.

Doğan, T., Sapmaz, F., ve Totan, T. (2011). Beden imgesi baş etme stratejileri ölçeğinin türkçe uyarlaması: Geçerlilik ve güvenilirlik çalışması. Anadolu Psikiyatri Dergisi, 12(2), 121-129.

Dökmen, Ü. (1994). İletişim çatışmaları ve empati. İstanbul: Sistem Yayıncılık, s. 5, 153-156.

Erözkan, A. (2007). Üniversite öğrencilerinin iletişim becerilerini etkileyen faktörler. Marmara Üniversitesi Atatürk Ĕ̈itim Fakültesi, Eğitim Bilimleri Dergisi, 26(26), 59-72.

Ertürk, Y. D. (2006). Bedenin iki yansıması: Bedenle iletişim, iletişimde beden. İstanbul Üniversitesi İletişim Fakültesi Dergisi, (24), 103-116.

Gautreau, C. M., Sherry, S. B., Mushquash, A. R., \& Stewart, S. H. (2015). Is self-critical perfectionism an antecedent of or a consequence of social anxiety, or both? A 12-month, three-wave longitudinal study. Personality and Individual Differences, 82, 125-130.

Gökçe H., Uygurtaş M., ve Morca Ş. (2018). Düzenli fiziksel etkinliklere katılan bireylerin serbest zaman doyumu serbest zamanlarda algllanan özgürlük ve sosyal görünüş kaygı düzeyleri. Uluslararası Rekreasyon ve Spor Yönetimi Kongresi, 10-13 Mayıs, Bodrum-Muğla/Türkiye.

Göksel, A.G., Caz, Ç., Yazıcı, Ö. F., \& Zorba, E. (2018). Spor hizmeti alan bireylerin sosyal görünüş kaygııs ve öznel mutluluklarının incelenmesi. Gaziantep Üniversitesi Spor Bilimleri Dergisi, 3(3), 88-101.

Hart, T. A., Flora, D. B., Palyo, S. A., Fresco, D. M., Holle, C., \& Heimberg, R. G. (2008). Development and examination of the social appearance anxiety scale. Assessment, 15(1), 48-59.

Hergüner, G., \& Yaman, Ö. G. M. (1997). Sporun üniversite öğrencilerinin iletişim beceri düzeylerine etkisi. Pamukkale Üniversitesi Ĕ̌itim Fakültesi Dergisi, 3(3), 95-1001.

Iş1kol Özge, F. (2013). Illköğretim II. kademe öğrencilerinin sosyal görünüş saygıları ile benlik saygıları arasındaki ilişkinin incelenmesi (Üsküdar İlçesi örneği). Yüksek Lisans Tezi, Yedi Tepe Üniversitesi Sosyal Bilimler Enstitüsü, İstanbul. 
Karasar, N. (2005). Bilimsel araştırma yöntemi (17. Baskı). Ankara: Nobel yayın dağıtım, 81-83.

Kılıç, M. (2015). Üniversite öğrencilerinin sosyal görünüş kaygıları ile benlik saygıları ve yalnızlık düzeyleri arasındaki ilişkinin incelenmesi. Yüksek lisans tezi. Selçk Üniversitesi, Sağlık Bilimler Enstitüsü, Konya.

Kumcağız, H., Yılmaz, M., Çelik, S. B., \& Avcı, İ.A. (2011). Hemşirelerin iletişim becerileri: Samsun ili Örneği. Dicle Medical Journal/Dicle Tip Dergisi, 38(1), 49-56.

Öngören, B. (2015). Sosyolojik açıdan sağlıklı beden imgesi. Sosyal ve Beşeri Bilimler Araştırmaları Dergisi, $16(34), 25-45$.

Özdinç, Ö. (2005). Çukurova üniversitesi öğrencilerinin sporun ve spora katilimin sosyalleşmeyle ilişkisi üzerine görüşleri. Spormetre Beden Eğitimi ve Spor Bilimleri Dergisi, 3(2), 77-84.

Pehlivan, Z., Ada, E. N., \& Öztaş, G. (2017). Ev kadınlarının sosyal görünüş kaygıları ve sağlıklı yaşam biçimi davranışları. Spor Bilimleri Dergisi, 28(1), 11-23.

Sabuncuoğlu, Z., \& Gümüş, M. (2008). Örgütlerde İletişim. İsanbul: Arıkan Yayıncılık.

Salar, B., Hekim, M., \& Tokgöz, M. (2012). 15-18 yaş grubu takım ve ferdi spor yapan bireylerin duygusal durumlarının karşılaştırılması. Mehmet Akif Ersoy Üniversitesi Sosyal Bilimler Enstitüsü Dergisi, (6), 123135 .

Saygıdeğer, A. (2004). Benlik saygısı düzeyleri farklı genel lise öğrencilerinin bazı kişisel özelliklerine göre iletişim becerilerine ilişkin algılarının incelenmesi. Yüksek Lisans Tezi. Anadolu Üniversitesi, Eğitim Bilimleri Enstitüsü.

Saygın, Y. (2008). Üniversite ögrencilerinin sosyal destek, benlik saygısı ve öznel iyi oluş düzeylerinin incelenmesi. Doktora Tezi. Selçuk Üniversitesi Sosyal Bilimler Enstitüsü, Konya.

Tabachnick, B. G., \& Fidell, L. S. (2007). Experimental designs using ANOVA (p.724). Belmont, CA: Thomson/Brooks/Cole.

Tepeköylü, Ö., Soytürk, M., Çamlıyer, H. (2009). Beden eğitimi ve spor yüksekokulu öğrencilerinin (BESYO) iletişim becerisi algılarının bazı değişkenler açısından incelenmesi. Spormetre Beden Eğitimi ve Spor Bilimleri Dergisi, 7(3), 115-124.

Tepeköylü-Öztürk, Ö., Soytürk, M., Daşdan-Ada, E. N., \& Çamlıyer, H. (2011). Üniversite takımlarında sporcu olan öğrencilerle spor yapmayan öğrencilerin iletişim becerisi düzeylerinin karşılaştırılması. Hacettepe Spor Bilimleri Dergisi, 22(2), 43-53.

Türk Dil Kurumu (TDK). (2020) https://sozluk.gov.tr/ Erişim tarihi: 02.02.2020.

Yıldıran, İ., \& Yetim, A. (1996). Orta öğretimde beden eğitimi dersinin öncelikli amaçları üzerine bir araştırma. Gazi Beden Ĕ̈itimi ve Spor Bilimleri Dergisi, 1(3), 36-43.

Zorba, E. (2012). Herkes için yaşam boyu spor, Neyir Yayınları, Ankara.

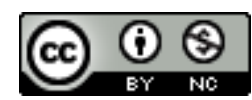

Bu eser Creative Commons Atıf-GayriTicari 4.0 Uluslararası Lisansı ile lisanslanmışır. 